\title{
The Vulgarization of the Language of a Children's Multiplication Text as a Psycholinguistic Problem
}

\section{Вульгаризація мови дитячого мультиплікаційного тексту як психолінгвістична проблема}

\author{
Miroslava Mamich \\ Dr. in Philology, Associate Professor, \\ Head of the Department of \\ Applied Linguistics
}

\author{
Мирослава Мамич \\ доктор філологічних наук, доцент, \\ завідувач кафедри прикладної \\ лінгвістики
}

E-mail: miroslavamiros@ukr.net orcid.org/0000-0002-2868-3953

\author{
National University \\ "Odessa Law Academy» \\ 23, Fontanska doroha Str., Odessa, \\ Ukraine, 65009
}

Начіональний університет «Одеська юридична академія» $\bowtie$ вул. Фонтанська дорога, 23, Одеса, Україна, 65009

Original manuscript received October 05, 2018

Revised manuscript accepted October 15, 2019

\begin{abstract}
Research aim is to identify the phenomena of verbal vulgarization of children's cartoon discourse, to determine their functional-semantic loads and registers of reduced emotional evaluation, as well as the main socio-cultural types of corporate vulgar behavior.
\end{abstract}

Research Methods. The study of the vulgarization of children's media content was carried out with the help of: a) theoretical methods, b) psycholinguistic empirical methods - discourse-analysis of vulgarized dialogical situations; questionnaire related to the testing of registers of dialogical situations in cinema texts among the audience of student's youth (80 humanitarian students (specialty "Journalism») of the National University "Odesa Law Academy» aged 17-20 years).

Results. The didactic role of animated cinema texts in the formation of media culture is noted. It was proposed the practical analysis of the modern children's cartoons 
The Vulgarization of the Language of a Children's Multiplication...

language in the context of the systematization of markers of affective vulgarity, such as slangisms, jargonisms, elements of common language, obscenisms. On the basis of a survey and psycholinguistic experiment, a stylistic evaluation of the perception of the selected lexical-phraseological material as such that contains the connotation "vulgarity» was confirmed, the attitude of the young generation of viewers to vulgarized cinema text was revealed.

Conclusions. Among the main conclusions we may note that as a result of language vulgarization of modern consciousness, in particular children, the so-called conceptual sphere of human activity is changing. The new generation of viewers is focused on low, coarse communication, on the weakening of the feeling of beautiful, on the positive perception of the appropriate aesthetics of everyday life. According to the results of the questionnaire, these cinema texts are perceived neutral by 55 students, positively - 21 students, negatively - 4 students. The language of cartoon characters, which represent certain social groups of real society, is seen as the norm for any situation, and grumpiness, disrespect, psycho-emotional imbalance are seen as their "organic" color. Therefore, the majority, or the vast majority of the respondents, correlated the lexical-phraseological units as jargon that is, acceptable in the youth environment. Modern foreign animation that is presented as translated cinema text, loses the important function of being a mediadidactive source, that is, the medium of producing patterns of individual and collective linguistic behavior.

Key words: cartoon discourse, speech of a children \& appose; multiplication film, children's media content, vulgarism, slangism, obsceneism, linguistic consciousness, adaptive potential of a person, stress tolerance.

\section{Вступ}

Основна тенденція у розвитку сучасної масової культури - це посилення плюралізації аргументів та оцінок, розширення жанровостильових різновидів усних форм спілкування, еволюція в бік увиразнення розмовності, що реалізується зокрема у вульгаризації спілкування, яке супроводжує психоемоційна напруга, а нерідко агресія. Саме цей емоційно-психологічний стан віддавна в колі уваги західних соціальних психологів (Berkowitz, 1962; Buss, 1971), які поведінкову агресію, зокрема вікову, пов'язують із вербальною (Goldstein, 2005), а також психолінгвістів, які в останні роки актуалізували увагу до проявів агресії через 3МI (Комалова, 2019). Науковці різних напрямків загострюють увагу на тому, що, на жаль, сформувалася i стала запитаною «негативна етика» (Донникова, 2018), що формує у мовної спільноти такі асоціативні зони, які акумулюють нові механізми мовно-культурної пам’яті. 
Дослідження сучасної мовної культури становлять основу культурно-історичної психолінгвістики (Bertau, 2011), яка потребує емпіричних результатів 3 різних зрізів діяльності індивідуальних когнітивних систем, поєднання соціальних і психологічних функцій різних словесних форм. Одна 3 найбільш актуальних у аспекті вивчення глобалізованої мовної свідомості - проблема вульгаризації сучасної мови. Невипадково дослідники мови західноєвропейських та українських медій зосереджуються на психологічних аспектах (Ставицька, 2005; Meskova, 2017; Таран, 2015; Кутуза, 2018; Cachola et al., 2018 та ін.) і констатують зміни лексичних стильових норм публічного дискурсу, формування «нових стандартів публічного спілкування за змішаним середньолітературним i літературно-фамільярним зразком» (Бибик, 2016: 72).

Відповідні проблеми 3 погляду психології пояснюють тим, що така мовна поведінка супроводжується: а) екстраверсивністю, викидом вульгарності, згрубілості, адже індивідуум долає страх перед змінами у довкіллі, стресами; у мові ж це виявляється як згрубілий, агресивний діалог, насичений вульгарними оцінками, жаргоном, лайливими, обсценними виразами і под.; б) усвідомленням власної свободи і волі, що змішуються у певної частини населення із поняттями сваволі, зокрема й мовної, із агресивними способами вирішення спірних питань і конфліктів, які частина населення сприймає як прояв сили, рішучості, мужності, впевненості і безкомпромісності; в) налаштуванням до «культуромовної розкутості» та тематичного плюралізму (зняття табу з певних тем), до зростання емоційності та несхвальної оцінності в побутовому середовищі (зокрема див.: Oliynyk \& Shevchenko, 2016: 77). При цьому слід звернути увагу на особливості функціонування мовлення як психічного феномену, прояви мовної стресостійкості, адаптогенності у зв'язку зі змінюваними обставинами. Психолінгвістичні спостереження виявляють усвідомлене послуговування ненормативними мовними засобами, значне посилення неусвідомленого прояву афективного вульгаризованого мовного ресурсу (Кожухарь, 2008; Јау, 2009), сліпого наслідування соціально табуйованих виразів і в усній, і в писемній практиці (Mackay, Hadley \& Schwartz, 2005). Дослідження складу i семантико-стилістичної структури такого «мовного арсеналу» уможливлює проектування результатів у контексті 
The Vulgarization of the Language of a Children's Multiplication...

психолінгвістичної теорії лексикону як надбання індивіда, яка вибудовується на засадах дисасоціативних - асоціативних зв'язків, які змінюються залежно від зміни середовища, 3 якого діти засвоюють мову, що і спричинює крім загальних, індивідуальні особливості їхньої мови (Kidd, Donnelly \& Christiansen, 2018).

Усі відзначені в ракурсі психолінгвістики аспекти мають екстралінгвальні передумови - економічні (розвиток конкуренції, спрямування сервісу до споживача, посилення міжнародних обмінів, переживання інфляційних процесів і процесів вивільнення робочої сили, переструктурування професійної діяльності), політичні (свобода слова, зняття політичної цензури), соціальні (соціальномайнова поляризація суспільства), демографічні, світоглядні, емоційно-настроєві, фізичний стан мовця - вульгаризації загальної мовної практики від 90-х рр. ХХ ст. і нині, під якою тут розуміємо згрубіле, непристойне, спрощене спілкування.

Новизна запропонованої статті у ракурсі психолінгвістичних досліджень у тому, що проблему вульгаризації мови розглядаємо на матеріалі українського кіно. Оскільки зарубіжні вчені приділяють увагу формуванню стратегії уникнення образливої мови в аудіовізуальному перекладі фільмів (Trupej, 2019), полікодовий кінематографічний дискурс використовують як базу для навчання мови, закріплення ситуативних комунікативних практик (Lavrinenko \& Shevchenko, 2019), але вони засвідчили схвальне/несхвальне ставлення до елементів вульгаризації мови дитячої мультиплікації. Автори таких творів не завжди враховують підготовленість свідомості сучасних дітей до перегляду і критичного сприймання цілих кінотворів, персонажі яких говорять так званою «сучасною дорослою» мовою, виявляючи при цьому здебільшого не раціональне, а емоційне ставлення до світу, ситуацій, пропагуючи, хоча й непрямо, анормативний тип мовної поведінки, моралі, викривлюючи шлях соціалізації особистості дитини. Отож, у цілому, враховуючи принцип агрегації в психології, можемо припускати, що девіативні (вульгаризовані) мовні манери персонажів можуть проектуватися на цілісний образ персонажа як стереотип, еталон неконтрольованої поведінки, зокрема й вербальної, яка не вимагає довгого обдумування, формулювання думки, а обмежується стереотипними вульгаризмами, коли стерта межа між особистим i загальним. Навіть психіатри зауважують про формування 
вульгарного стилю життя - стилю деградації людських стосунків, а психологи відзначають серед причин вульгаризації свідомості брак спілкування, тісних контактів людей (Верду, 2013).

Широкий погляд на питання вульгаризації комунікації у світі спонукає у перспективі до іï окреслення у рамках психолінгвістики, об'єктом якої серед іншого є різні вияви мовленнєвої поведінки. Запропоноване дослідження актуалізує проблеми перекладу англомовних кінотекстів, адаптованих для різновікової глядацької аудиторії 3 різним емоційно-психологічним станом зрілості i критичного ставлення до світу, зокрема представленого в аудіовізуальних асоціативно-образних моделях, які охоплює мультиплікаційний художній субдискурс як фрагмент дитячого медіаконтенту.

Mema дослідження - виявити явища вербальної вульгаризації дитячого мультиплікаційного дискурсу, визначити їхнє функціонально-семантичне навантаження і підтвердити/спростувати такі кваліфікацї за допомогою психолінгвістичного експерименту та анкетування. У зв'язку 3 цим серед завдань дослідження фіксація, систематизація та функціонально-семантичний опис засобів вульгарної комунікації; установлення регістрів зниженої емоційної оцінки; окреслення основних соціокультурних типажів корпоративної вульгарної поведінки; визначення психологічних і соціокультурних передумов вульгаризації мови дітей-глядачів.

\section{Методи та методики дослідження}

У теоретико-методологічну основу вивчення вульгаризації екранної культури, зокрема мови дитячих мультиплікаційних фільмів як складників дитячого медіаконтенту, покладено: а) теоретичні методи, спрямовані на визначення понять дослідження, аналіз наукових джерел інформації щодо зазначених проблем, б) поєднання лінгвістичних i психологічних емпіричних методів дискурс-аналізу вульгаризованих діалогічних ситуацій у текстах дитячих мультиплікаційних фільмів, що уможливив встановлення функціонально-семантичного навантаження виокремлених елементів зниження регістрів спілкування між певними соціокультурними психотипами персонажів; анкетування, пов’язаного 3 
The Vulgarization of the Language of a Children's Multiplication...

тестуванням регістрів діалогічних ситуацій у текстах дитячих мультиплікаційних фільмів в аудиторії студентської молоді з метою підтвердження / спростування тези щодо вульгаризації екранного субдискурсу. В експерименті-анкетуванні (вересень 2018 р.) взяли участь 80 студентів-гуманітаріїв (спеціальність «Журналістика») Національного університету «Одеська юридична академія» віком 17-20 років (Анкета. 1. Позначте мультфільми, які Вам відомі: «Аладдін», «Мегамозок», «Футурама», «Панда Кунг-фу», «Тачки», «Роби ноги», «Рік та Морті», «Губка Боб», «Грифіни», «Мулан», «Літачки», «Зоряні війни», «Льодовиковий період», «Нікчемний Я». 2. У якому віці Ви вперше подивилися ці мультфільми? 3. Як Ви оцінюєте рівень мовлення цих мультфільмів? 4. Визначте стилістичні ознаки наведених слів і виразів: вульгарне (в), згрубіле (3), несхвальне (н), жаргонне (ж), лайливе (л). Поставте відповідну позначку (для аналізу запропоновано понад 30 діалогічних висловлень).

\section{Результати та дискусії}

Для аналізу зібраного матеріалу важливе правильне потрактування ключового поняття - вульгарність. Коли ведемо мову про вульгаризацію сучасної мови екрану, а надто мови дитячого медіаконтенту, кінотекстів для дітей, мультиплікації, то основний акцент робимо не на зовнішніх, поведінкових, фізіологічних, культурно-естетичних параметрах, зображальних якостях, а на змістовому складникові мультиплікаційного дискурсу - його текстах, його зануренні в межі реальності. У зв'язку з цим психологи постійно звертають увагу батьків на те, що діти до трьох років взагалі не повинні дивитися мультфільми (під впливом прив'язаності до екрана ослаблюються i блокується рухова активність, мотивація до спілкування, предметної діяльності), а діти від 5-7 років повинні їх дивитися «дозовано», оскільки у ці два періоди активізуються різні поведінкові механізми, які пропонує екранний кінотекст - яскравий, динамічний. Крім того, особлива увага фахівців наразі прикута до якості «диснеївської» продукції, яка, перекладена українською мовою, також не завжди відповідає культурно-естетичним еталонам мовної спільноти. Ці еталони 
тісно переплетені із емоційно-особистісними запитами соціуму, відповідального за формування наступних поколінь (опитувані студенти на питання 2 анкети відповіли, що вони дивилися відповідні мультфільми у віці 3-16 років).

Поняття «вульгарність» лише на позір зрозуміле i легко трактоване. Насправді, формуючи завдання 4 анкети, ми зіткнулися 3 нечітким його тлумаченням. Поєднуючи усі семантичні складники поняття вульгарність, що їх подають відповідні статті Словника української мови в 11-ти т. за редакцією І.К. Білодіда (Білодід, 1970-1980), отримаємо значення: це те, що пов'язане з грубістю, безкультур'ям, неввічливістю, непристойністю - у поведінці, вчинках, висловленнях, що характеризується надто спрощеним змістом, інфантильністю. Тобто вульгаризація пов'язана 3 порушенням морально- та вербально-етичних норм, вона $є$ соціальним маркером «низу». Нагадаємо, що 3 поняттям «вульгарність»у л лінгвістиці пов'язані ще певні регістри емоційно-експресивної, аксіологічної шкали: несхвальне, знижене, згрубіле, лайливе. Відомо, що у лексикографії застосовують спеціальну стилістичну позначку вульг. Отже, і вульгарні лексеми, і слова із ремарками несхв., лайл., згруб./ груб., зниж., жарг., арго можуть утворювати синонімічні ряди номінацій, яку стилізують діалоги в художньому дискурсі, зокрема персонажів зазначених вище мультиплікаційних кінотекстів.

Персонажами цього жанру дитячого медіаконтенту $\epsilon$, крім казкових дружніх героїв, базарний крадій, супергерої, воїни, суперзлодії, суперледі, мутанти, людиноподібні істоти, лихі «амігос», егоїстичні чоловіки, які люблять випити, покурити, схильні до гомосексуалізму й клептоманії істоти, навіжений учений тощо, тобто стилізовані, лялькові образи представників певних соціальних груп. Їхню мову впізнаємо за манерами спілкуватися, а мову кінотексту кваліфікуємо як таку, що в багатьох ситуаціях асоціюється 3 грубістю, невигадливістю, тобто «вульгарністю як соціальним явищем» (Левонтина, 2004: 239). На цю особливість звертає особливу увагу Ф.Є. Прилипко (2019), досліджуючи мову сучасної перекладної мультиплікації на більш широкому матеріалі; щоправда, ті дискурсивні одиниці, що $є$ предметом нашого дослідження, кваліфіковано як розмовні, що мають низький стилістичний регістр, i просторічні. Така оцінка не суперечить загальному розумінню i розмовності як такої, і вульгарності зокрема. 
The Vulgarization of the Language of a Children's Multiplication...

За кількісним вираженням, жаргонізми превалюють у ряду вульгаризованого лексикону. Насамперед у мультиплікаційних діалогах відзначаємо велику частку кримінальних жаргонізмів, що здебільшого увійшли в молодіжне комунікативне середовище. Це невипадково, адже за сценаріями цитованих нижче кінотекстів деякі події пов'язані з тими, хто відбував покарання в тюрмі. Серед таких жаргонізмів, наприклад, оцінні слова (Бендер: Пиво! Халявне пиво! («Футурама»); По: Внутрішній спокій? Це кльово (Ставицька, 2007: 272: Кльово, крим., мол., схвальн. Добре, чудово). Внутрішній спокій де? («Панда Кунг-фу»)). Чимало вторинних номінацій із зниженим стилістичним забарвленням, як-от: Яго: Ну все! Капець! (Кондратюк, 2006: 155: Капець, зниж. Кінець; дуже погано) Tорба! (Кондратюк, 2006: 291: Торба. Безвихідна ситуація, кінець) Викопайте могилку на двох, бо нам тепер гайки (Кондратюк, 2006: 291: Гайки; мол. Кінець, безвихідна ситуація) («Аладдін»); Бандит 2: Ми заклали бомбу на його підступі. Бандит: Ніштяк («Тачки») (Ставицька, 2007: 238: Ніштяк, крим., мол. Усе гаразд, добре); По: Все! Годі изих загадок. Негайно коліться! (Кондратюк, 2006: 134: Колотись, -люся, -лешся, недок.; крим. $i$ мол. Розкривати інформацію) («Панда Кунг-фу»); Аїд: $Я$ в курсі, щуо ви в курсі. Я в ӥхав (Ставицька, 2007: 181: в'їду, в'їдеш, док., (у що); мол., крим. Зрозуміти, осмислити щось), врубився (Ставицька, 2007: 195: Врубився, -аюся, -аєшся, недок. у що, мол., жарг. Розуміти щось), до мене дійшло! («Аладдін»); По: Я сьогодні облаэсався, як ніхто в історії кунг-фу (Ставицька, 2007: 40: Облажався крим., мол., Помилково потрапити у незручне становище) («Панда Кунг-фу»); Бендер: Чисте кидалово (Кондратюк, 2006: 158: Кидалово-а, с.; мол. Підлість, обман, видурювання грошей]. У мене на сьогодні особливих планів нема. Ходімо бухати («Футурама»). Із цього ряду прикладів студенти-гуманітарії усі виділені слова кваліфікували переважно як жаргонні, крім «бухати», якому здебільшого давали узагальнену стилістичну кваліфікацію вульгарне (27), а також жаргонне (16), несхвальне (17).

Ряд лексем із відтінком згрубілості (на думку студентів, як це засвідчують і лексикографічні джерела, це жаргонізми (спокуха (72), крутяк (66)) з характерними суфіксами згрубілості -ак, -ух, -ос: Крабс: Замовлення було простеньке. Боб: Опануй себе, Юджене. Спокуха! (Ставицька, 2007: 309: Спокуха, мол., жрм., жарт., 
ірон., Заклик до спокою) («Губка Боб»); Павук: Ви теж геній? Ой, незручняк («Людина-павук»); Самер: Тепер в тебе буде власний пістолет. Морті: Крутяк (Ставицька, 2007: 192: Вищій рівень чогось); Фрай: Бендере, подумай про сеньорит. Бендер: Попадос (Кондратюк, 2006: 244: Попадос. Дуже неприємна ситуація) («Футурама»).

Засвідчені в досліджуваному дитячому медіаконтенті сталі звороти у відповідних лексикографічних джерелах марковані як «кримінальне», «молодіжне», що давно свідчить про злиття двох типів мовної свідомості, пор.: Бендер: Чесно, без балди («Футурама»); Злодій 1: Починайте [виводити машини 3 ладу]. Злодій 2: Без базару («Тачки») (Ставицька, 2007: 42: Базар, мол., жрм, крим. Бесіда, розмова. Базару (базарів) не має. Уживається на знак згоди). Виокремлені у висловленнях слова кваліфіковано під час лінгвостилістичного експерименту переважно як жаргонні (36 та 66 відповідно).

Приклади функціонування згрубілого лексикону, лексики iз несхвальною оцінкою засвідчують акцент мультиплікаторів на низьких регістрах комунікації, на відтворенні та підтримці вульгаризованого психолінгвального механізму спілкування: Пінгвін: Галька-ималька, пащани, ми $і$ без того круті, що хай. В’їхав, кудлатий? («Роби ноги»); Самер: Годі, Ріку. Ти довів, щзо маєш раиію. Доперла («Рік та Морті»); Блискавка: Тут усе безкоштовно. Обалдеть. А чого ж я тут втикаю? (Кондратюк, 2006: 90: Втикати. Дивитись у нікуди, абстрагуватись від дійсності); Нані: Не треба, Ліло і так влипла (Кондратюк, 2006: 85: Вляпались. Потрапляти у неприємну ситуацію) («Ліло і Стич»); Самер: Це називають карпедія, Морті. Ти не шариш («Рік та Морті»); Чоловік: Та не парся (Кондратюк, 2006: 223: Паритись. Хвилюватися, перейматися чимось). Пітер: Хм. Про це я $i$ не подумав («Грифіни»). Учасники лінгвостилістичного експерименту кваліфікували в основному словоформи в'їхав (52), втикаю (49), шариш (59) як жаргонні, що засвідчує, на нашу думку, те, що цей лексикон асоціюється в учасників анкетування 3 мовою свого соціального середовища.

Серед зрубілих комунікативних одиниць - фразеологізми, що засвідчують виразно негативне, різко несприйнятливе ставлення до пропозицій персонажів, що також є стилізацією нетактовного спілкування, ведення діалогів «на нервах»: Вонг: 3 цүією зброєю ми 
The Vulgarization of the Language of a Children's Multiplication...

зможемо врятувати тварин. Бендер: Нa фiz треба (Кондратюк, 2006: 305: На фіг, груб. варіант. Та ну його) («Футурама»). Таку саму різко негативну психоемоційну ситуацію трансформують вульгарні вигукові одиниці (їхніми відповідниками в середньолітературному стандарті спілкування можуть бути «це ж треба», «ого, оце так» відповідно): Пітер: Йолки (Кондратюк, 2006: 151: Йолки, виг., вульг. Незадоволення), ти не можеш мене звільнити («Грифіни»)); Пірат: (відкриває книгу) Hi фiza собі (Кондратюк 2006: 305: Фіг, вульг. Нічого. Нi фiга - Ого, оце так)! Бібліотечна заборгованість («Футурама»). Виділені лексико-фразеологічні одиниці студенти оцінили як лайливе (35) та жаргонне (32) відповідно.

Як вульгаризм (за оцінкою учасників анкетування - згрубіле (33), лайливе (26)) кваліфікують лексикографи наказову форму «заткнись», наприклад: Орел 2: Ой, не зачіпай изю тему. Орел: Заткніться (Бусел, 2005: 427: Затикатися, тільки док., перен., вульг. Перестати говорити; замовкнути)! Ласторукий поставив проникливе запитання («Футурама»).

На жаль, не позбавлена мова сучасної дитячої мультиплікації й такого вияву вульгарності, як лайлива лексика (більшість опитуваних - 30,0-60,0\% таку кваліфікацію підтверджують), що трансформує глядачеві негативні емоції - невдоволення, обурення, категоричність оцінок, непримиренність 3 обставинами, лихослів'я, наприклад: Маман (обурена невдачею): Трясия (Бусел, 2005: 1483: Трясця. Уживається як лайливе слово)! («Футурама»); Сандокан: Диявол (Бусел, 2005: 302: Диявол. Уживається як лайливе слово), як я маю знати, у якому будинку імператор? («Спайдермен»). Частина зазначених вульгаризмів - це в усталеному розумінні вигуки як прямі маркери негативних емоцій, психоемоційного стану роздратування, яке проектується і на психічний стан глядача: Продавець: Добрий день. Останній аромат від «Келвін клон». Вонг: Чорт забирай! (Білоноженко, 1993: 242: Чорт забирай. Уживається для висловлення невдоволення, обурення, досади чи захоплення, здивування і т. ін.) («Футурама»); Браєн: Якого дідька! (Білоноженко, 1993: 242: Якого дідька. Навіщо, нащо, для чого) («Грифіни»); Сирник: [позасловникове]. У когось є серветка? («Тачки»); Фрай: Хрінувато. У трубі пара («Тачки»); Кенон: Чорта з два (Білоноженко, 1993: 953: Чорта $з$ два, вульг. Уживається для вираження заперечення, незгоди та ін.) («Зоряні війни»). Такі складники діалогів дитячої 
мультиплікації інтенсифікують відмову, адже адресант категорично не бажає погоджуватися зі співрозмовником: Грю: Так, та вона ж не нормальна. Хай їм чорт (Білоноженко, 1993: 952: Хай їм чорт. Уживається для вираження сильного незадоволення) $з$ тим побаченням («Нікчемний Я»).

На жаль, не оминають автори діалогів і вульгаризовану увагу до тілесності, що виражене зокрема у лайливих репліках (таку стилістичну ознаку підтвердили 50,0-55,0\% опитуваних) 3 відповідними номінаціями (От лайно; Лайно собаче; От срань): Рік: Цьомни мене у дупу («Рік та Морті»).

Стилізовані діалоги мультиплікаційного кінотексту відбивають вульгаризовані форми звертання один до одного. Засвідчуємо у відповідних уривках згрубіло-просторічні словоформи як прояв позаетикетного, неповажного звертання до співрозмовника, зокрема в мультфільмі «Тачки»: Сирник: Альо, а шо картопля вродила?; Корабель: Альо гаражж, ану шуруй звідси. Учасники анкетування дали визначення виділеним словам як жаргонізмам (55).

Унаочнити результати лінгвостилістичного експерименту можна у такому зіставленні (табл. 1).

Таблиця 1. Семантична, словникова та експериментальна кваліфікація вульгаризмів

\begin{tabular}{|c|c|c|}
\hline $\begin{array}{c}\text { Різновид лексичного } \\
\text { (фразеологічного) } \\
\text { вульгаризму }\end{array}$ & Лексикографічна ремарка & $\begin{array}{c}\text { Кваліфікація учасників } \\
\text { експерименту } \\
\text { (80 анкет) }\end{array}$ \\
\hline $\begin{array}{l}\text { Жаргонне (халявний, кльово, } \\
\text { капець, торба, гайки, } \\
\text { ніштяк, колотися, в '̈̈хати, } \\
\text { врубитися, облажатися, } \\
\text { кидалово, бухати; ФО - } \\
\text { без балди; без базару). }\end{array}$ & $\begin{array}{l}\text { крим., мол. (Кондратюк, } \\
2006 ; \text { Ставицька, 2007); } \\
\text { зниж. (Кондратюк, 2006). }\end{array}$ & $\begin{array}{l}\text { Жаргонні слова - від } 16 \text { до } \\
61 \text { підтвердження. } \\
\text { Жаргонні ФО - } 36 \text { та } 66 \\
\text { відповідно. } \\
\text { Проте: } \\
\text { бухати - вульгарне (27), } \\
\text { жаргонне (16), } \\
\text { несхвальне (17). }\end{array}$ \\
\hline $\begin{array}{l}\text { Згрубіле (в їхати, доперти, } \\
\text { втикати, шарити, паритися, } \\
\text { влипнути; спокуха, } \\
\text { незручняк, крутяк, попадос; } \\
\text { ФО-на фіг треба; } \\
\text { ні фіга собі). }\end{array}$ & $\begin{array}{l}\text { груб., вульг. (Білодід, 1970- } \\
1980 ; \text { Кондратюк, 2006); } \\
\text { мол., жрм. (Ставицька, } \\
2007 ; \text { Кондратюк, 2006). }\end{array}$ & $\begin{array}{l}\text { Жаргонні слова - вӥхав (52), } \\
\text { втикаю (49), шариш (59), } \\
\text { крутяк (66), спокуха (72). } \\
\text { Згрубілі ФО - лайливе (35) } \\
\text { та жаргонне (32) відповідно. }\end{array}$ \\
\hline Вульгарне (заткнутися). & вульг. (Бусел, 2005). & $\begin{array}{l}\text { згрубіле (33), лайливе (26), } \\
\text { несхвальне (16), вульгарне } \\
(3), \text { жаргонне (2). }\end{array}$ \\
\hline
\end{tabular}


The Vulgarization of the Language of a Children's Multiplication...

Лайливе (трясияя, диявол, хрінувато; ФО - чорт забирай; сорьон батон; чорта з два, хай їм чорт; от лайно; лайно собаче; от срань; изьомкни мене в дупу). лайл., вульг. (Бусел, 2005; : Лайливі слова - від 30 до 43 Білоноженко, 1993). підтверджень щодо кожного із наведених слів і зворотів, як жаргонні - від 4 до 24 підтверджень.

Оскільки тлумачні загальномовні словники та словники жаргонної лексики не враховують у ремаркуванні всю аксіологічну шкалу (із запропонованої диференціації «несхвальне», «знижене», «згрубіле», «вульгарне», «лайливе»), то запроваджений у дослідженні поділ вульгаризованого слово- та фразеовживання спирається i на функціонально-семантичні ознаки виділених оцінних та номінативних одиниць. Учасники ж експерименту застосували в тій чи іншій мірі усю градацію стилістичних відтінків для кваліфікації відповідних комунікативних одиниць, віддаючи перевагу кваліфікації «жаргонне». Їхні оцінки, сформовані під впливом медіатекстів, що обиралися для аналізу, не завжди збігаються із науковим регістром вульгаризованого лексикону української мови. Утім, студенти щодо кожного зі слів чи фразеологізмів зазначили також кваліфікацію «несхвальне», «знижене» (від 3 до 17 підтверджень щодо кожного i3 слововживань), що свідчить про загальну оцінку культури висловлення у виділених для аналізу діалогічних єдностях.

\section{Висновки}

Отже, мова сучасних дитячих мультиплікаційних фільмів, відзначена маркерами вульгарності, впливає на естетичне сприймання людини, на формування у покоління дітей-глядачів налаштування на низьке, згрубіле спілкування, на ослаблення відчуття прекрасного, на позитивне сприймання відповідної естетики повсякдення (за результатами анкетування зазначені кінотексти сприймають нейтрально 55 студентів, позитивно 21 студент, негативно - 4 студенти). Мова персонажів мультфільмів, які представляють певні соціальні прошарки реального суспільства, сприймається як норма для будь-яких ситуацій, а згрубілість, зневажливість, психоемоційна неврівноваженість - як їх «органічне» забарвлення (невипадково більшість, або переважна більшість 
опитуваних співвідносила виділені для стилістичної оцінки лексикофразеологічні одиниці як жаргонні, тобто прийнятні в молодіжному середовищі). Оскільки діти та підлітки відкриті до сприймання стереотипів екранної продукції як реальності, то відповідна й мовна поведінка «диснеївських» улюбленців, орієнтована на «дорослу» моду у спілкуванні, на економію мовних зусиль, пов'язану зі сленгізацією, жаргонізацією, лайливістю, на прагнення при цьому бути чи то кумедним, «своїм», чи то надто впевненим, наступально-войовничим. Тому, на жаль, у подальшому більшість індивідуумів, соціум взагалі може зберігати надто високу планку стресостійкості, яка породжуватиме нові кола не лише вербальної, а й психоемоційної, соціокультурної вульгаризації, співвіднесеної 3 унормуванням гнівливості, роздратованості, несприйнятливості не лише в міжособистісному побутовому, але й професійному спілкуванні. Крім того, сучасна іноземна мультиплікація, представлена як перекладений кінотекст, втрачає важливу функцію бути медіадидактичним джерелом, тобто середовищем продукування зразків індивідуальної і колективної мовної поведінки, поширення певного соціального досвіду.

Перспективою подальших психолінгвістичних розвідок у контексті поставленої проблеми $\epsilon$ вивчення соціокультурних факторів вульгарності на різноманітному за жанровими ознаками матеріалі, розширення вікових і соціальних груп мовців / глядачів (зокрема й батьків дітей) 3 метою проведення моніторингу, спрямованого на встановлення адаптаційних меж у колективному та індивідуальному сприйманні кінотекстів із соціально татуйованими елементами, текстів інтернет-комунікації відповідної якості, на убезпечення подальшої вульгаризації національно-мовної спільноти, на маркування мультиплікаційної продукції як такої, що має обмежені кола споживачів.

\section{Література}

Білодід, І.К. (Ред.). (1970-1980). Словник української мови (Т. 1-11). Київ: Наукова думка.

Бибик, С.П. (2016). Оновлена стильова норма засобів масової інформації. Украйнська мова, 2, 72-81.

Верду, В. (2013). Вульгарность становится показателем органического разложения человека. Режим доступа: http://www.sdelanounih.ru/vulgarnoststanovitsya-pokazatelem-organicheskogo-razlozheniya-cheloveka/ 
The Vulgarization of the Language of a Children's Multiplication...

Бусел, В.Т. (Ред.). (2005). Великий тлумачний словник сучасної украӥнської мови. Київ; Ірпінь: ВТФ «Перун».

Донникова, И.А. (2018). Нравственный поиск в мультикультурной коммуникации. Антропологічні виміри філософських досліджень, 14, 30-41. https://doi. org/10.15802/ampr.v0i14.150545

Кожухарь, Г.С. (2008). Формы межличностной толерантности: критериальные признаки и особенности. Психологический журнал, 29(3), 30-40.

Комалова, Л.Р. (2019). Репрезентация вербального образа акта агрессии в информационном универсуме англоязычных СМИ. Вестник Российского университета дружбы народов, 23(1), 149-164.

Кондратюк, Т.Н. (2006). Словник сучасного украӥнського сленгу. Харків: Фоліо.

Кутуза, Н.В. (2018). Комунікативна сугестія в рекламному дискурсі: психолінгвістичний аспект. Київ: Видавничий дім Дмитра Бураго.

Левонтина, И.Б. (2004). Осторожно, пошлость! Логический анализ языка. Языки эстетики: Концеептуальные поля прекрасного и безобразного (с. 231-250) Москва: Индрик.

Прилипко, Ф.С. (2019). Лексико-фразеологічні комунікеми в сучасному дитячому мультиплікаційному фільмі. (Автореф. дис. канд. філол. наук). Київ.

Ставицька, Л. (2005). Арго, жартон, сленг. Київ: Критика.

Ставицька, Л.О. (2007). Украӥнський жаргон: словник. Київ: Критика.

Білоноженко, В.М. (Ред.). (1993). Фразеологічний словник української мови. Київ: Наукова думка.

Таран, О. (2015). Психолінгвальні чинники функціонування сленгових одиниць. Studia Ukrainica Posnaniensia, 3, 337-343. https://doi.org/10.14746/ sup.2015.3.43

Berkowitz, L. (1962). Aggression: a Social Psychological Analysis. N.Y.

Bertau, M.-C. (2011). Language for the Other: Constructing Cultural Historical Psycholinguistics. Tätigkeitstheorie: E-Journal for Activity Theoretical Research in Germany, 5, 13-49.

Buss, A. (1971). Aggression Pays. The Control of Aggression and Violence (pp. 7-18). N.Y., London: Academic Press.

Cachola, I., Eric Holgate, E., Preotiuc-Pietro, D., \& Jessy, Li J. (2018). Expressively vulgar: The socio-dynamics of vulgarity and its effects on sentiment analysis in social media. Proceedings of the 27th International Conference on Computational Linguistics (pp. 2927-2938). Santa Fe, New Mexico, USA.

Jay, T. (2009). The utility and ubiquity of taboo words. Perspectives on Psychological Science, 4(2), 153-161. https://doi.org/10.1111/j.1745-6924.2009.01115.x

Goldstein, A. (2005). Catch It Low to Prevent It High: Countering Low-Level Verbal Abuse. Retrieved from https://www.cyc-net.org/cyc-online/cycol-1005-goldstein.html

Kidd, E., Donnelly, S., \& Christiansen, H.M. (2018). Individual Differences in Language Acquisition and Processing. Trends in Cognitive Sciences, 22(2), 154 169. https://doi.org/10.1016/j.tics.2017.11.006

Lavrinenko, I., \& Shevchenko, I. (2019). Turn-taking in cinematic discourse: linguistic characteristics and practical implications for esp teaching. Advanced Education, 12, 49-54. https://doi.org/10.20535/2410-8286.155922

Mackay, G.D., Hadley, B.C., \& Schwartz, H.J. (2005). Relations between emotion, illusory word perception, and orthographic repetition blindness: Tests of binding theory. The Quarterly Journal of Experimental Psychology, 58(8), 1514-1533. https://doi.org/10.1080/02724980443000728 
Meskova, L. (2017). Translation of vulgarism in Mass media. XLinguae Journal, 10(3), 101-109. https://doi.org/10.18355/XL.2017.10.03.08

Oliynyk, N., \& Shevchenko, I. (2016). Conceptualisation of economic crisis in discourse: from the great depression to the great recession. Advanced Education, 6, 76-81. https://doi.org/10.20535/2410-8286.78867

Trupej, J. (2019). Avoiding Offensive Language in Audio-visual Translation: A Case Study of Subtitling from English to Slovenian. Across Languages and Cultures, 20(1), 57-77. https://doi.org/10.1556/084.2019.20.1.3

\section{References}

Bilodid, I.K. (Ed.). (1970-1980). Slovnyk ukrainskoi movy [Dictionary of Ukrainian language] (Vols. 1-11). Kyiv: Naukova dumka [in Ukrainian].

Bybyk, S.P. (2016). Onovlena stylova norma zasobiv masovoyi informatsiyi [Updated media stylesheet]. Ukrayinska mova - Ukrainian language, 2, 72-81 [in Ukrainian].

Verdu, V. (2013). Vulgarnost stanovitsya pokazatelem organicheskogo razlozheniya cheloveka [Vulgarity becomes an indicator of the organic decomposition of man]. Retrieved from http://www.sdelanounih.ru/vulgarnost-stanovitsya-pokazatelemorganicheskogo-razlozheniya-cheloveka/ [in Russian].

Busel, T. (Ed.). (2005). Velykyi tlumachnyi slovnyk suchasnoii ukraiinskoii movy [Big explanatory dictionary of modern Ukrainian language]. Kyiv; Irpin: VTF «Perun» [in Ukrainian].

Donnikova, I.A. (2018). Nravstvennii poysk v multykulturnoi kommunykatsyy [Moral search in multicultural communication]. Antropologihni vymiry filosofskyh doslidzhen - Antropolohichni vymiry filosofskykh doslidzhen, 14, 30-41. https:// doi.org/10.15802/ampr.v0i14.150545 [in Russian].

Kozhuhar, G.S. (2008). Formy meghlichnostnoi tolerantnosti: kriterialnye priznaki $\mathrm{i}$ osobennosti [Forms of interactional tolarance: criteria and peculiarities]. Psihologicheskiy zhurnal - Psychological Journal, 29(3), 30-40 [in Russian].

Komalova, L. (2019). Reprezentatsyia verbalnoho obraza akta ahressyy v ynformatsyonnom unyversume anhloiazichnikh [Representation of the Verbal Image of Aggression in the Informational Universe of the English-Language Mass Media]. Vestnyk Rossyiskoho unyversyteta druzhbi narodov - Russian Journal of Linguistics, 23(1), 149-164 [in Russian].

Kondratiuk, T.N. (2006). Slovnyk suchasnoho ukrayinskoho slenhu [Dictionary of modern Ukrainian slang]. Kharkiv: Folio [in Ukrainian].

Kutuza, N.V. (2018). Komunikatyvna suhestiia $v$ reklamnomu dyskursi: psykholinhvistychnyi aspect [Communicative suggestion in advertisement discourse: psycholingual aspect]. Kyiv: Vydavnychyi dim Dmytra Buraho [in Ukrainian].

Levontina, I.V. (2004). Ostorozhno, poshlost! [Careful, vulgarity]. Logicheskiy analiz yazyka. Yazyki estetiki: Kontseptualnyye polya prekrasnogo $i$ bezobraznogo Logical analysis of the language. Languages of aesthetics: Conceptual fields of beauty and ugliness] (pp. 231-250). Moscow: Indrik [in Russian].

Prylypko, F.Ye. (2019). Leksyko-frazeolohichni komunikemy v suchasnomu dytyachomu multyplikatsiynomu filmi [Lexicon-phraseological communicemas in the modern children's cartoon film]. Candidate's thesis. Kyiv [in Ukrainian]. 
The Vulgarization of the Language of a Children's Multiplication...

Stavyts'ka, L. (2005). Argo, zhargon, slenh [Argo, zhargon, sleng]. Kyiv: Krytyka [in Ukrainian].

Stavyts'ka, L.O. (2007). Ukrayinskyy zharhon: slovnyk [Ukrainian jargon: Dictionary]. Kyiv: Krytyka [in Ukrainian].

Bilonozhenko, V.M. (Ed.). (1993). Frazeolohichnyy slovnyk ukrayinskoyi movy [Phraseological Dictionary of the Ukrainian Language]. Kyiv: Naukova dumka [in Ukrainian].

Taran, O. (2015). Psykholinhvalni chynnyky funktsionuvannia slenhovykh odynyts [Psycholingual factors of slang units' functioning]. Studia Ukrainica Posnaniensia. Studia Ukrainica Posnaniensia, 3, 337-343. https://doi. org/10.14746/sup.2015.3.43 [in Ukrainian].

Berkowitz, L. (1962). Aggression: a Social Psychological Analysis. N.Y.

Bertau, M.-C. (2011). Language for the Other: Constructing Cultural Historical Psycholinguistics. Tätigkeitstheorie: E-Journal for Activity Theoretical Research in Germany, 5, 13-49.

Buss, A. (1971). Aggression Pays. The Control of Aggression and Violence (pp. 7-18). N.Y., London: Academic Press.

Cachola, I., Eric Holgate, E., Preotiuc-Pietro, D., \& Jessy, Li J. (2018). Expressively vulgar: The socio-dynamics of vulgarity and its effects on sentiment analysis in social media. Proceedings of the 27th International Conference on Computational Linguistics (pp. 2927-2938). Santa Fe, New Mexico, USA.

Jay, T. (2009). The utility and ubiquity of taboo words. Perspectives on Psychological Science, 4(2), 153-161. https://doi.org/10.1111/j.1745-6924.2009.01115.x

Goldstein, A. (2005). Catch It Low to Prevent It High: Countering Low-Level Verbal Abuse. Retrieved from https://www.cyc-net.org/cyc-online/cycol-1005-goldstein.html

Kidd, E., Donnelly, S., \& Christiansen, H.M. (2018). Individual Differences in Language Acquisition and Processing. Trends in Cognitive Sciences, 22(2), 154 169. https://doi.org/10.1016/j.tics.2017.11.006

Lavrinenko, I., \& Shevchenko, I. (2019). Turn-taking in cinematic discourse: linguistic characteristics and practical implications for esp teaching. Advanced Education, 12, 49-54. https://doi.org/10.20535/2410-8286.155922

Mackay, G.D., Hadley, B.C., \& Schwartz, H.J. (2005). Relations between emotion, illusory word perception, and orthographic repetition blindness: Tests of binding theory. The Quarterly Journal of Experimental Psychology, 58(8), 1514-1533. https://doi.org/10.1080/02724980443000728

Meskova, L. (2017). Translation of vulgarism in Mass media. XLinguae Journal, 10(3), 101-109. https://doi.org/10.18355/XL.2017.10.03.08

Oliynyk, N., \& Shevchenko, I. (2016). Conceptualisation of economic crisis in discourse: from the great depression to the great recession. Advanced Education, 6, 76-81. https://doi.org/10.20535/2410-8286.78867

Trupej, J. (2019). Avoiding Offensive Language in Audio-visual Translation: A Case Study of Subtitling from English to Slovenian. Across Languages and Cultures, 20(1), 57-77. https://doi.org/10.1556/084.2019.20.1.3

\section{АНОТАЦІЯ}

Мета дослідження - виявити явища вербальної вульгаризації дитячого мультиплікаційного дискурсу, визначити їхнє функціонально-семантичне 
навантаження і регістри зниженої емоційної оцінки, а також основні соціокультурні типажі корпоративної вульгарної поведінки.

Методики дослідження. Вивчення вульгаризації дитячого медіаконтенту здійснено за допомогою: a) теоретичних методів, б) психолінгвістичних емпіричних методів - дискурс-аналізу вульгаризованих діалогічних ситуацій; анкетування, пов'язаного з тестуванням регістрів діалогічних ситуацій у кінотекстах в аудиторії студентської молоді (80 студентів-гуманітаріїв (спеціальність «Журналістика») Національного університету "Одеська юридична академія» віком 17-20 років).

Результати. Відзначено дидактичну роль мультиплікаційних кінотекстів у формуванні медіакультури. Запропоновано практичний аналіз мови сучасних дитячих мультиплікаційних фрільмів у контексті систематизації маркерів афективної вульгарності - сленгізмів, жаргонізмів, елементів просторіччя, обсценізмів. На основі опитування і психолінгвістичного експерименту підтверджено стилістичну оцінку сприймання виділеного лексикофразеологічного матеріалу як такого, що містить конотацію 'вульгарність', виявлено ставлення молодого покоління глядачів до вульгаризованого кінотексту.

Висновки. Серед основних висновків застережено, що в результаті вульгаризації мовної свідомості сучасників, зокрема дітей, змінюється так звана концептуальна сфера діяльності людини. Нове покоління глядачів налаштоване на низьке, згрубіле спілкування, на ослаблення відчуття прекрасного, на позитивне сприймання відповідної естетики повсякдення. За результатами анкетування зазначені кінотексти сприймають нейтрально 55 студентів, позитивно - 21 студент, негативно - 4 студенти. Мова персонажів мультфільмів, які представляють певні сочіальні прошарки реального суспільства, сприймається як норма для будь-яких ситуацій, а згрубілість, зневажливість, психоемоційна неврівноваженість - як їх "органічне» забарвлення. Тому більшість, або переважна більшість опитуваних співвідносила виділені для стилістичної оцінки лексико-фразеологічні одиниці як жаргонні, тобто прийнятні в молодіжному середовищі. Сучасна іноземна мультиплікація, представлена як перекладений кінотекст, втрачає важливу функцію бути медіадидактичним джерелом, тобто середовищем продукування зразків індивідуальної і колективної мовної поведінки.

Ключові слова: мова дитячого мультиплікаційного фрільму, вульгаризм, сленгізм, обсценізм, мовна свідомість, адаптаційний потенціал особистості, стресостійкість.

Мамич Мирослава. Вульгаризация языка детского мультипликационного текста как психолингвистическая проблема

\section{АННОТАЦИЯ}

Цель исследования - выявить явления вербальной вульгаризации детского мультипликационного дискурса, определить их функкционально-семантическую 
The Vulgarization of the Language of a Children's Multiplication...

нагрузку и регистры пониженной эмоциональной оценки, а также основные социокультурные типажи корпоративного вульгарного поведения.

Методики исследования. Изучение вульгаризации детского медиаконтента осуществлено с помощью: а) теоретических методов, б) психолингвистических эмпирических методов - дискурс-анализа вульгаризированных диалогических ситуаций; анкетирования, связанного с тестированием регистров диалогчческих ситуаций в кинотекстах в аудитории студенческой молодежи (80 студентов-гуманитариев (специальность "Журналистика») Национального университета "Одесская юридическая академия» в возрасте 17-20 лет).

Результаты. Отмечено дидактическую роль мультипликационных кинотекстов в формировании медиакультуры. Предложено практический анализ языка современных детских мультипликационных фильмов в контексте систематизации маркеров афрективной вульгаризации - сленгизмов, жаргонизмов, элементов просторечия, обсценизмов. На основе опроса и психолингвистического эксперимента подтверждено стилистическую оценку восприятия выделенного лексико-фразеологического материала как содержащего коннотацию "вульгарность", выявлено отношение молодого поколения зрителей к вульгаризированному кинотексту.

Выводы. Среди основных выводов оговорено, что в результате вульгаризации языкового сознания современников, в частности детей, меняется так называемая концептуальная сфера деятельности человека. Новое поколение зрителей настроено на низкое, грубое общение, на ослабление чувства прекрасного, на положительное восприятие соответствующей эстетики повседневности. По результатам анкетирования указанные кинотексты воспринимают нейтрально 55 студентов, положительно - 21 студент, отрицательно - 4 студента. Язык персонажей мультфильмов, которые представляют определенные социальные слои реального общества, воспринимается как норма для любых ситуаций, а грубость, пренебрежительность, психоэмоциональная неуравновешенность - как их "органическуе» окраску. Поэтому подавляющее большинство опрошенных соотносила выделенные для стилистической оченки лексико-фразеологчческие единицы как жаргонные, то есть приемлемые в молодежной среде. Современная иностранная мультипликация, представленная как переведенный кинотекст, теряет важную функцию быть медиадидактичним источником, то есть средой продуцирования образцов индивидуального и коллективного речевого поведения.

Ключевые слова: мультипликационный дискурс, речь детского мультипликационного фильма, детский медиаконтент, вульгаризм, сленгизм, обсценизм, языковое сознание, адаптационный потенциал личности, стрессоустойчивость. 